\author{
УДК 519.866:[330.341.1+330.332] \\ DOI: $10.25140 / 2411-5215-2020-4(24)-7-15$ \\ Валерій Ільчук, Тетяна Шпомер
}

\title{
ПРОБЛЕМИ МОДЕЛЮВАННЯ ІННОВАЦІЙНО-ІНВЕСТИЦЙНИХ СИСТЕМ ВІДНОВЛЮВАЛЬНОЇ СФЕРИ ЕКОНОМІКИ
}

\section{Валерий Ильчук, Татьяна Шпомер
ПРОБЛЕМЫ МОДЕЛИРОВАНИЯ ИННОВАЦИОННО-ИНВЕСТИЦИОННЫХ СИСТЕМ ВОЗОБНОВЛЯЕМОЙ СФЕРЫ ЭКОНОМИКИ

\section{Valerii Ilchuk, Tetiana Shpomer \\ PROBLEMS OF MODELING OF INNOVATION AND INVESTMENT SYSTEMS OF THE RECOVERY SPHERE OF ECONOMY}

\begin{abstract}
У статті розглянуто актуальні проблеми інтенсифікаџії інноваційно-інвестиційних процесів в економіці України иляхом посилення ролі нових інтеграційних структур - інноваційно-інвестичійних систем. Доведено необхідність проведення системного аналізу та системного моделювання як ефективних інструментів дослідження таких систем. Наведено підхід до моделювання інноваційно-інвестиційних систем щуо передбачає три етапи: розробка ресурсної моделі, побудова ресурсно-економічної моделі та інноваційно-економічної моделі. Визначено основні елементи, щзо враховуються в побудові сценаріїв розвитку інноваційно-інвестиційних систем.

Ключові слова: нацуінальна інноваційна система; системний підхід; інноваційно-інвестиційна система; відновлювальна сфера національної економіки.

Рис.: 1. Бібл.: 12.

В статье рассматриваются актуальные проблемы интенсификации инновационно-инвестиционньх процессов в экономике Украины путем усиления роли новых интеграционных структур - инновационно-инвестиционных систем. Доказана необходимость проведения системного анализа и системного моделирования как эффективньх инструментов исследования таких систем. Приведен подход к моделированию инновационно-инвестиционньх систем предусматривающий три этапа: разработка ресурсной модели, построение ресурсно-экономической модели и инновационно-экономической модели. Определены основные элементы, которые учитываются в построении сиенариев развития инновачионно-инвестиционных систем.
\end{abstract}

Ключевые слова: национальная инновационная система; системный подход; инновационно-инвестиционная система; возобновляемая сфера национальной экономики.

Рис.: 1. Библ.: 12.

The article considers topical problems of intensification of innovation and investment processes in the economy of Ukraine by strengthening the role of new integration structures - innovation and investment systems. The necessity of system analysis and system modeling as effective tools for research of such systems is proved. An approach to modeling innovation and investment systems is presented, which involves three stages: development of a resource model, construction of a resource-economic model and innovation-economic model. The main elements that are taken into account in the construction of scenarios for the development of innovation and investment systems are identified.

Keywords: national innovation system; system approach; innovation and investment system; regenerative sphere of national economy.

Fig.: 1. References: 12.

JEL Classification: G0; $\mathrm{O} 30$

Постановка проблеми. Досягнення сучасної економічної науки і практики інноваційного оновлення виробництва потребують подальшого осмислення напрямів і темпів розвитку національної економіки.

Необхідно дослідити вузлові питання теорії інноваційно-інвестиційного оновлення техніко-технологічної бази реального сектору економіки в рамках наукового напряму, що стосується становлення і розвитку інноваційно-інвестиційних систем (IIC). Відповідно до такого підходу особлива увага приділяється актуальним та недостатньо ще висвітленим в економічній літературі проблемам організації та інституційної підтримки інноваційно-інвестиційних процесів, які б забезпечили прискорений технологічний розвиток вітчизняного виробництва.

У методологічному обгрунтуванні механізмів інноваційно-інвестиційних зрушень основну роль відіграє системний підхід до процесів і явищ, засобів і методів, суб'єктів і об'єктів, інформаційного супроводу та різного роду зв'язків і т. ін., що забезпечують сам процес інноваційного оновлення виробництва.

(C) Ільчук В. П., Шпомер Т. О., 2020 
3 погляду системного підходу побудова функціональної структури IIC дозволяє виявити узагальнені зв'язки, які існують між різними складовими системи, якісно нові властивості підсистем та елементів.

Перехід від вивчення окремих суб'єктів інноваційно-інвестиційної сфери економіки до розгляду інноваційно-інвестиційних систем, їхнього місця, функцій і зв'язків окремих суб'єктів у зазначеній системі $є$ ефективним методом дослідження нових формувань, їх призначення та ролі в процесі інноваційно-інвестиційного оновлення та розвитку національної економіки.

Аналіз останніх досліджень і публікацій. Питанням дослідження проблем інноваційного розвитку виробничих підприємств, інтенсифікації інноваційно-інвестиційних процесів у реальному секторі економіки присвячені фундаментальні праці таких науковців і дослідників, як М. Алієв, О. Амоша, О. Бородіна, В. Геєць, М. Гаман, М. Гладій, О. Гончаренко, Б. Данилишин, О. Жилінська, Н. Іванова, О. Колодізєв, О. Марченко, П. Микитюк, С. Онишко, Є. Сич, О. Федірко, Л. Федулова, В. Федоренко, Л. Яремко та ін., які зробили вагомий внесок у розвиток категоріального апарату економічної науки, у вирішення методологічних проблем ресурсного забезпечення інновацій, у розробку схем та механізмів інвестування інноваційних зрушень у реальному секторі національної економіки.

Виділення недосліджених частин загальної проблеми. Віддаючи належне проведеним дослідженням, на сьогодні залишаються невирішеними питання активізації інноваційних процесів у реальному секторі економіки, підвищення ефективності інноваційно-інвестиційної діяльності, дослідження нових системних утворень - інноваційноінвестиційних систем, які формуються у відновлювальній сфері національної економіки й перебувають на перших етапах свого життєвого циклу.

Мета досліджень - виявлення передумов, причин та факторів, що сприяють формуванню в інноваційно-інвестиційному середовищі нових системних утворень - інноваційно-інвестиційних систем.

Основними завданнями дослідження є теоретичне обгрунтування структури інноваційно-інвестиційної системи, визначення іiї ролі в інноваційному оновленні виробництва, виявлення принципових відмінностей інноваційно-інвестиційної системи від національної інноваційної системи.

Теоретичною і методологічною основою досліджень є наукові праці класиків економічної науки з теорії систем і системного підходу, праці й публікації провідних учених і фахівців із проблем інноваційного оновлення економіки.

У статті використано методи, які базуються на сучасних теоретико-методологічних підходах, зокрема: методи абстрагування, узагальнення, системного аналізу, синтезу і т. ін., що дозволило розробити теоретико-методологічні засади формування нових інтеграційних структур - інноваційно-інвестиційних систем.

Виклад основного матеріалу. Низький інноваційний рівень виробництва, технологічне відставання національної економіки від економік провідних країн світу пояснюється не виваженістю державної інноваційної політики, недосконалістю механізмів державного регулювання інноваційної діяльності, відсутністю належної фінансової підтримки фундаментальних і прикладних досліджень.

Завдання, що покладались на національну інноваційну систему щодо інноваційного оновлення вітчизняного виробництва, усунення технологічного відставання України від розвинених країн світу та формування статусу України як високотехнологічної держави залишились невирішеними.

Головна причина низької ефективності функціонування національної інноваційної системи полягає в неналежному фінансовому забезпеченні інноваційної діяльності. Практика вдалих інноваційних зрушень показала, що інноваційний процес $є$ ефективним за умов повноцінного інвестиційного забезпечення. 
ТЕОРЕТИЧНІ ПРОБЛЕМИ РОЗВИТКУ НАЦІОНАЛЬНОЇ ЕКОНОМІКИ

Тобто інноваційний та інвестиційний процеси мають реалізовуватись сумісно як складові єдиного інноваційно-інвестиційного процесу. Звідси національна інноваційна система має трансформуватись у більш досконалу - інноваційно-інвестиційну систему, тобто в систему вищого рівня, де інноваційна система поряд з інвестиційною стають ії складовими підсистемами.

Звідси формування інноваційно-інвестиційної системи (IIC) різних рівнів - від корпоративного і до національного рівня є закономірним і об’єктивним процесом.

До функцій IIC належить реалізація на належному рівні всіх стадій інноваційноінвестиційного процесу - фундаментальні дослідження, прикладні дослідження, дослідно-конструкторські роботи, виготовлення дослідних зразків, випробування, налагодження та доведення дослідного зразка та організація виробництва інноваційної продукції.

Ситуація, яка склалась у відновлювальній сфері національної економіки, спонукала до виникнення певних об'єктивних причин, які стали передумовою формування IIC. До таких причин слід віднести:

1. Сучасний стан інноваційного розвитку національної економіки засвідчує інноваційну кризу вітчизняного виробництва. Національна інноваційна система не виконує свою головну функцію - інноваційного оновлення реального сектору економіки, у результаті відсутності необхідного обсягу інвестицій, що зумовлене недосконалістю інституційного та інфраструктурного забезпечення інвестиційних процесів.

2. Підвищення складності і трудомісткості інноваційних рішень, зростання вартості інтелектуальної праці, збільшення витрат на розробку й реалізацію інновацій вимагає посилення інвестиційного супроводу інноваційних процесів, що можливо забезпечити шляхом формування нових інтегральних структур - інноваційно-інвестиційних систем.

3. Інвестиційна складова в інноваційній системі, яка існує як елемент системи, не в змозі повноцінно виконувати функцію інвестиційного забезпечення інновацій. Звідси інноваційна система не має повноцінного ресурсу для реалізації інноваційних процесів.

4. Ресурс інноваційного оновлення за допомогою інноваційно-інвестиційних систем має більші потенційні можливості в результаті переходу інвестиційної складової, що $\epsilon$ елементом інноваційної системи, на рівень підсистеми більш досконалої системи.

5. Більш складні системи, якими є інноваційно-інвестиційні, порівняно з інноваційними мають більшу результативність ще й тому, що синергетичний ефект системи детермінується ступенем їх складності. Чим системи складніші, досконаліші, тим більший синергетичний ефект у них формується.

Методологічні проблеми дослідження систем, що функціонують в інноваційноінвестиційній сфері зумовлюють виникнення нових завдань економічних досліджень, пов'язаних зі специфікою інноваційного розвитку певних секторів національної економіки. Це стосується аналізу структури системи, виділення та дослідження певних іiі елементів, їх взаємозв'язків і т. ін.

Системний підхід до визначення місця та ролі учасників інноваційноінвестиційного процесу в технологічному оновленні виробництва, їх взаємозв'язків, ступеня інтегративності тощо дає змогу виділити найбільш суттєві сторони їх відносин, виявити загальну мету у спільній діяльності й формалізувати функції зазначеної сукупності суб'єктів і явищ та інших елементів і подати їх як систему.

Виявлені інноваційно-інвестиційні системи характеризуються складною внутрішньою структурою, мають певну ієрархічну побудову 3 притаманною сукупністю зв'язків, операцій і т. ін. і функціонують із чітко визначеною метою (рис. 1). Вказані системи дозволяють застосовувати при їх дослідженні накопичений в інших галузях знань досвід дослідження подібних систем. 
ІННОВАЦЙНО-ІНВЕСТИЦЙНА СИСТЕМА

\section{УПРАВЛІНСЬКА ПІДСИСТЕМА (КООРДИНАЦІЙНИЙ ЦЕНТР)}

\section{(підсистема першого рівня)}

Елементи: Президент України (Рада з питань науково-технологічної політики); Верховна Рада України (Комітет з питань науки і освіти); Кабінет Міністрів України (Управління науково-технічного та гуманітарного розвитку); Рада національної безпеки і оборони України (міжвідомча комісія з питань науковотехнологічної безпеки); Міністерство освіти і науки (департамент інноваційного розвитку, департамент науково-технологічного розвитку), інші управлінські структури та підрозділи, що спрямовані на інноваційний розвиток національної економіки

\begin{tabular}{|c|c|c|c|c|}
\hline \multicolumn{5}{|c|}{ Підсистеми першого рівня } \\
\hline \multicolumn{3}{|c|}{ ІННОВАЦІЙНА ПІДСИСТЕМА } & \multicolumn{2}{|c|}{ ІНВЕСТИЦЙНА ПІДСИСТЕМА } \\
\hline & Підсистеми другого рівня & & Підсистеми & другого рівня \\
\hline Науково-дослідна & Інноваційно-впровадницька & Виробничо-технологічна & Реального інвестування & Фінансового інвестування \\
\hline \begin{tabular}{|l}
\multicolumn{1}{c|}{ Елементи: } \\
- засоби та методи генерації \\
новацій, ї аналізу та вибору; \\
- новатори (індивідуальні \\
винахідники або науково- \\
дослідні колективи); \\
- складові науково-дослідної \\
інфраструктури (НДІ, КБ, \\
проектно-конструкторські \\
технологічні бюро з \\
відповідною матеріально- \\
технічною базою і т. ін.)
\end{tabular} & \begin{tabular}{|l}
\multicolumn{1}{c}{ Елементи: } \\
- засоби, методи та \\
механізми матеріалізації \\
(впровадження) інновацій; \\
- фізичні особи: менеджери, \\
підприємці, що сприяють \\
впровадженню нового \\
проєкту або технології; \\
- складові інноваційно- \\
впровадницької \\
інфраструктури: інноваційні, \\
інжинірингові та \\
консалтингові підприємства, \\
інноваційні центри \\
трансферу технологій і т. ін.
\end{tabular} & \begin{tabular}{l}
\multicolumn{1}{c}{ Елементи: } \\
- засоби, методи та \\
механізми передачі \\
інновацій по комунікаційним \\
каналам (дифузія інновацій); \\
- фізичні особи, що сприяють \\
процесу дифузії інновацій; \\
- складові виробничо- \\
технологічної \\
інфраструктури (інноваційно \\
орієнтовані та інші \\
високотехнологічні \\
підприємства і т. ін., що \\
здатні налагодити випуск \\
інноваційної продукції)
\end{tabular} & \begin{tabular}{l}
\multicolumn{1}{c}{ Елементи: } \\
- інвестори (фізичні та юридичні \\
особи); \\
- схеми, методи та механізми \\
залучення та акумуляції коштів \\
інвесторів; \\
- схеми, методи та прийоми \\
інвестування розвитку \\
виробництва; \\
- складові інфраструктури \\
(банківські та інші фінансово- \\
кредитні установи, що беруть \\
участь у реальному інвестуванні \\
виробництва)
\end{tabular} & $\begin{array}{l}\text { Елементи: } \\
\text { - інвестори (фізичні та юридичні } \\
\text { особи); } \\
\text { - механізми, методи та } \\
\text { інструменти залучення коштів } \\
\text { широких верств населення } \\
\text { переважно акціонерного капіталу; } \\
\text { - схеми, методи та інструменти } \\
\text { інвестування розвитку } \\
\text { виробництва; } \\
\text { - складові інвестиційної } \\
\text { інфраструктури, інвестиційні } \\
\text { фонди, компанії, венчурні фонди } \\
\text { та інші, установи біржової та } \\
\text { позабіржової фондової } \\
\text { торговельної системи (мережа } \\
\text { фінансових посередників - } \\
\text { торговців цінними паперами } \\
\text { і т. ін.) }\end{array}$ \\
\hline
\end{tabular}

Рис. 1. Складові та елементи інноваційно-інвестиційної системи національного рівня 
ТЕОРЕТИЧНІ ПРОБЛЕМИ РОЗВИТКУ НАЦІОНАЛЬНОЇ ЕКОНОМІКИ

Системний підхід дозволяє досліджувати виявлені системи шляхом моделювання. Процес моделювання є досить точним інструментом дослідження, який дає змогу виділити найбільш суттєві зв'язки і відношення, які є предметом дослідження [11].

IIC є об'єктом дослідження, який поділяється на складові - підсистеми та елементи, вивчення яких є окремим завданням для більш глибокого пізнання механізму та сутності інноваційно-інвестиційних процесів.

Формування інноваційно-інвестиційних систем, удосконалення їхньої структури, накопичення відновлювального потенціалу шляхом розвитку їхніх складових систем і елементів дозволяє підтримувати внутрішню упорядкованість, стійкість до впливу збурюючих факторів зовнішнього середовища, вирішувати складні завдання інноваційного розвитку національної економіки.

Ефективність функціонування IIC залежить не тільки від їхньої внутрішньої упорядкованості, а й від рівня управління окремими складовими вказаних систем, здатності знайти ефективні механізми взаємодії різних суб'єктів інноваційно-інвестиційної сфери, оптимізувати їх взаємовідносини між собою.

Таким чином, інноваційно-інвестиційна теорія акцентує увагу на принциповій єдності інноваційно-інвестиційних процесів, поступовості й послідовності переходу на новий рівень результату, завдяки взаємозв'язку певних суб'єктів інноваційноінвестиційної сфери.

Необхідність дослідження складних систем, що розвиваються, і якими є IIC, вимагає застосування системного моделювання.

Початковим етапом системного моделювання є попередній системно-якісний аналіз складних соціально-економічних систем, до яких відносяться IIC. Це дає змогу виявити і проаналізувати системоутворюючі фактори, розкрити відповідні аспекти становлення та розвитку IIC. Оскільки IIC притаманні різні види діяльності окремих підсистем і елементів, то сама постановка завдання про дослідження цих систем передбачає інтеграцію знань із різних сфер діяльності: інвестиційної, інноваційної, науково-технічної, управлінської та ін. саме з цієї причини системний аналіз кожної складової підсистеми, кожної конкретної задачі проводиться групою спеціалістів з різних галузей знань, а системне моделювання придбає міждисциплінарний характер [8].

Основним етапом у системному моделюванні є побудова адекватної моделі шляхом формалізації структури системи, виділенні зв'язків і відносин між суб'єктами, які склалися в процесі становлення та функціонування IIC.

Багатопланова функціональність складних систем, до яких належить IIC, не піддається абсолютній формалізації в моделюванні, проте відносна формалізація не тільки можлива, а й необхідна.

Системне моделювання пов'язано з застосуванням методів декомпозиції системи. Усі математичні методи декомпозиції системи базуються на поділі досліджуваної системи на підсистеми, для кожної з яких необхідно вирішувати окрему задачу меншої розмірності. Що стосується підсистем IIC - інноваційної, інвестиційної, управлінської та ін., які пов'язані між собою, то загальне рішення можливо одержати в ході ізольованого рішення таких підзадач [11]. Звідси IIC як складна система характеризується гносеологічною особливістю системного моделювання, що виявляється в багатомодельності. Тобто загальна математична модель IIC може мати тільки умовний, формальний характер і досліджувати іiї аналітичними методами дуже складно.

Системна моделювання як ефективний інструмент дослідження IIC загалом підпадає під загальне визначення моделювання і володіє певними гносеологічними особливостями [11]. Ці гносеологічні особливості визначають ефективність методу моделю- 
вання при вивченні таких складних систем, як IIC. У цьому випадку в моделі відтворюються всі етапи інноваційного оновлення техніко-технологічної бази виробництва починаючи від генерації ідей і до їх матеріалізації.

Системність загальної моделі та її динамізм дозволяють комплексно відображати всю сукупність процесів інноваційного оновлення з їх суперечностями, багатогранністю та єдністю і водночас розкривати подальші можливості інноваційного розвитку виробництва.

Відпрацьована модель має адекватно відтворювати особливості функціонування IIC, іiї ціннісні орієнтири, які визначаються інноваційними пріоритетами розвитку суспільного виробництва.

При переході від порівняно простих за структурою IIC, які функціонують на рівні корпорації або асоціації підприємств, до більш масштабних, які функціонують на рівні галузі, регіону або на рівні національної економіки, де зростає складність і системи мають більш виражений ієрархічний характер, збільшується інтенсивність інформаційних потоків, ускладнюються взаємозв'язки між елементами системи і т. ін., що ускладнює моделювання таких систем і суттєво збільшує трудомісткість дослідження.

Головна мета моделювання IIC - це глибоке дослідження їхніх властивостей, функціональних зв'язків між складовими підсистемами й елементами тощо, що спрямовується на пошук оптимальних режимів її функціонування.

Функціонування IIC пов'язано зі споживанням різних видів ресурсів, а саме інформаційних, інвестиційних, інтелектуальних, енергетичних і т. ін., що забезпечує інноваційне оновлення та розвиток матеріально-технічної бази виробництва. Головні завдання IIC пов'язані зі створенням та впровадженням нової техніки та технології в суспільному виробництві. Науково-технічний прогрес і потреби суспільства зумовлюють зміну структури технологій по багатьом видам виробництва. У цих умовах головним завданням IIC $\epsilon$ забезпечення цього процесу. Реалізація будь-якого процесу пов'язана зі споживанням певних видів ресурсів. 3 цього погляду IIC, яка реалізує інноваційно-інвестиційний процес, $\epsilon$ ресурсною системою. Досвід моделювання довгострокового розвитку ресурсних систем дозволив визначити схему їх дослідження, яка складається з трьох етапів [8].

На першому етапі розробляється ресурсна модель. Усі способи інноваційного оновлення поділяються на основні альтернативи, що зумовлюється можливими схемами й механізмами інвестування.

Характеристика технологічного рівня існуючих у теперішній час виробничих потужностей та вибір прийнятних джерел і механізмів інвестування за певним способом їх інноваційного оновлення визначають вихідний стан (технологічну структуру) IIC як динамічного утворення.

У початковій структурі домінують традиційні технології (основані на використанні традиційних схем та джерел фінансування). У подальшому проводиться підбір нових схем, технологій та джерел фінансових ресурсів, які застосовуються в інноваційному оновленні виробництва.

Далі проводиться комплексний, системний аналіз та оцінка кожної із виділених технологій, за яких оцінюється ефективність процесу інноваційного оновлення.

Вибір кращої технології може здійснюватись за допомогою експертних оцінок або на основі спеціально розроблених імітаційних моделей по кожній технології, яка реалізує певний процес інноваційного оновлення.

Такий аналіз дозволяє виявити переваги і недоліки кожної відновлювальної технології, яка реалізується в рамках ресурсної моделі IIC. 
ТЕОРЕТИЧНІ ПРОБЛЕМИ РОЗВИТКУ НАЦІОНАЛЬНОЇ ЕКОНОМІКИ

У ресурсній моделі попит на всі види ресурсів, у тому числі й на інвестиційні, залежить як від ступеня інноваційного оновлення (модернізація, реконструкція, створення нових виробничих потужностей і т. ін.), так і технологією інноваційного оновлення основних засобів виробництва у плані використання певних схем, методів і механізмів інвестування.

Це зумовлює свій відбиток на процесі інноваційного оновлення і призводить до необхідності другого етапу моделювання - побудови ресурсно-економічної моделі.

Ресурсно-економічна модель враховує доступність і вартість ресурсу, ступені інноваційного оновлення за різними схемами інвестування з урахуванням нетрадиційних джерел інвестування.

Аналіз процесу інноваційного оновлення, спрямованого на досягнення певного технологічного рівня матеріально-технічної бази виробництва, що реалізується IIC за різних технологій інвестування дозволяє виявити їхню оптимальну структуру з погляду ресурсного забезпечення, використання інноваційного потенціалу та ефективності управління інноваційно-інвестиційним процесом.

Радикальність та значущість інноваційного оновлення основних засобів виробництва вітчизняних підприємств (на рівні кращих вітчизняних зразків, на рівні світових зразків, на рівні перспективних розробок, що перевищують наявні світові зразки) може бути охарактеризовано інноваційно-економічною моделлю. Ця модель повинна враховувати нові здобутки науково-технічного прогресу, які втілюються в процес інноваційного оновлення виробництва.

Розробка зазначених моделей може мати велике прикладне значення. Їх дослідження дозволить розкрити потенційні можливості IIC щодо інноваційного оновлення виробництва.

Важливим завданням є оптимізація інноваційно-інвестиційних процесів, що реалізуються в рамках IIC.

Актуальним при дослідженні функціонування IIC $є$ врахування невизначеності, що $€$ вагомим фактором при виборі стратегії розвитку зазначених систем.

Моделювання інноваційно-інвестиційних процесів і розгляд пріоритетів інноваційного розвитку виробництва передбачає врахування широкого спектра явищ, процесів $\mathrm{i}$ закономірностей, які охоплюють різні сфери та рівні інноваційного оновлення матеріально-технічної бази виробництва.

Значна складність всього комплексу інноваційно-інвестиційних процесів і взаємозв'язків між ними обумовлює ті обставини, що значна частина існуючих та значущих 3 погляду розвитку IIC факторів не може бути зведена до такої форми, яка б дозволила їх безпосереднє врахування в зазначених вище моделях.

Багатоаспектність IIC охоплює безліч факторів, взаємодія яких і вплив на інноваційно-інвестиційний процес мають бути формалізовані з метою оптимізації параметрів інноваційного оновлення виробництва, починаючи 3 верхнього рівня - національної економіки і закінчуючи нижнім рівнем - корпоративним, де на рівні підприємств вирішуються проблеми інноваційного оновлення основних засобів виробництва.

До основних елементів, що враховуються в побудові сценаріїв розвитку IIC, можна віднести:

- суб'єкти інноваційної та інвестиційної сфери економіки;

- корпоративні інтереси суб'єктів інноваційно-інвестиційного процесу;

- стратегічні цілі інноваційного оновлення матеріально-технічної бази виробництва;

- об’єкти, які підлягають певній формі інноваційного оновлення;

- ресурси, які необхідні для реалізації певної форми інноваційного оновлення;

- характер відносин між учасниками інноваційно-інвестиційного процесу;

- існуючі схеми, механізми та технології інноваційного оновлення виробництва; 
- нормативно-правове поле інноваційно-інвестиційної діяльності;

- місце та значущість проблем інноваційного оновлення певного підприємства, галузі, регіону в загальнонаціональній стратегії інноваційного оновлення національної економіки.

Інноваційне оновлення виробництва в рамках IIC може бути досягнуто за рахунок різних факторів, схем і механізмів залежно від того, якими пріоритетами, цілями і програмами керуються виконавці при реалізації певної стратегії інноваційного розвитку національної економіки.

Висновки та пропозиції. Дослідження процесів інноваційного оновлення вітчизняних підприємств виявило актуальні організаційно-економічні проблеми, вирішення яких $\epsilon$ необхідним для забезпечення інноваційного розвитку національної економіки.

Темпи інноваційного розвитку підприємств реального сектору економіки показують наявність гострих проблем у подоланні технологічного відставання України від провідних країн світу.

Формування IIC є об'єктивним процесом інтеграції суб'єктів відновлювальної сфери економіки, що викликано необхідністю посилення інвестиційної складової в процесі інноваційного розвитку економіки. IIC відображають сутність організаційноекономічних відносин між суб'єктами інноваційної та інвестиційної сфери в процесі інноваційно-інвестиційного розвитку національної економіки.

Удосконалення структури IIC, підвищення ефективності їх функціонування потребує подальших досліджень зазначених системних утворень, що передбачає використання системного моделювання.

Вивчення IIC відкриває новий напрям досліджень складних соціально-економічних систем, спрямованих на прискорення інноваційно-інвестиційних процесів у реальному секторі національної економіки.

\section{Список використаних джерел}

1. Гальчинський А., Геєць В., Семиноженко В. Інноваційна стратегія українських реформ. Київ : Знання України, 2002. 336 с.

2. Иванов В. В. Национальные инновационные системы: опыт формирования и перспективы развития. Инновачии. 2002. № 4. С. 14-18.

3. Ільчук В. П. Інноваційно-інвестиційні системи залізничного транспорту: оновлення та розвиток / за ред. д-ра екон. наук, проф. Є. М. Сича. Київ : Логос, 2004. 381 с.

4. Інноваційна складова економічного розвитку: монографія / за ред.. чл.-кор. НАНУ Л. К. Безчасного. Київ : IЕ НАН України, 2000. 260 с.

5. Капица С. П., Курдюмов С. П., Малинецкий Г. Г. Синергетика и прогнозы будущего. Москва : Наука, 1997. 285 с.

6. Макаренко И. П. Инновационно-инвестиционная политика в кризисной фазе экономического цикла. Наука и науковедение. 1996. № 3-4. С. 110-123.

7. Михайловська О.В. Місце та роль спеціальних економічних утворень в інтеграційних процесах. Науковий вісник Київського національного торговельно-економічного університету. 2003. № 6. С. 56-62.

8. Могилевский В. Д. Основы теории систем. Москва : МИРЭА, 1997. 190 с.

9. Сич Є. М., Ільчук В. П. Інноваційно-інвестиційний розвиток залізничного транспорту. Київ : Логос, 2002. 256 с.

10. Сич Є. М., Ільчук В. П. Інноваційно-інвестиційні комплекси транспортної галузі: методологія формування та розвитку: монографія. Київ : Логос, 2006. 264 с.

11. Уемов А. И. Системный подход и общая теория систем. Москва : Мысль, 1978. 272 с.

12. Черваньов Д. М., Нейкова Л. І. Менеджмент інноваційно-інвестиційного розвитку підприємств України. Київ : Знання, КОО, 1999. 514 с. 


\section{References}

1. Halchynskyi, A., Heiets, V., Semynozhenko, V. (2002). Innovatsiina stratehiia ukrainskykh reform [Innovative strategy of Ukrainian reforms]. Znannia Ukrainy.

2. Ivanov, V. V. (2002). Natsionalnye unnovatsionnye sistemy: opyt formirovaniia i perspektivy razvitiia [National innovation systems: experience of the formation and prospects of the development]. Innovatsii - Innovations, (4), pp. 14-18.

3. Ilchuk, V. P., Sycha, Ye. M. (2004). Innovatsiino-investytsiini systemy zaliznychnoho transportu: onovlennia ta rozvytok [Innovation and investment systems of railway transport: renewal and development]. Logos.

4. Bezchasnoho, L. K. (2000). Innovatsiina skladova ekonomichnoho rozvytku [The innovative component of the economic development]. IE NAN Ukrainy.

5. Kapytsa, S. P., Kurdiumov, S. P., Malynetskyi, H. H. (1997). Sinerhetika i prognozy budushcheho [Synergetics and forecasts of the future]. Nauka.

6. Makarenko, I. P. (1996). Innovatsionno-investitsionnaia politika v krizisnoi faze ekonomicheskogo tsikla [Innovation and the investment policy in the crisis phase of the economic cycle]. Nauka i naukovedenie - Science and research on research, (3-4), pp. 110-123.

7. Mykhailovska, O. V. (2003). Mistse ta rol spetsialnykh ekonomichnykh utvoren v intehratsiinykh protsesakh [The place and role of special economic entities in the integration processes]. Naukovyi visnyk Kyivskoho natsionalnoho torhovelno-ekonomichnoho universytetu Scientific Bulletin of Kyiv National University of Trade and Economics, (6), pp. 56-62.

8. Mogilevskii, V. D. (1997). Osnovy teorii sistem [Fundamentals of the systems theory]. MIREA.

9. Sych, Ye. M., Ilchuk, V. P. (2002). Innovatsiino-investytsiinyi rozvytok zaliznychnoho transportu [The innovation and investment development of railway transport]. Logos.

10. Sych, Ye. M., Ilchuk, V. P. (2006). Innovatsiino-investytsiini kompleksy transportnoi haluzi: metodolohiia formuvannia ta rozvytku [Innovation and investment complexes of the transport industry: methodology of the formation and development]. Logos.

11. Uemov, A. I. (1978). Sistemnyi podkhod i obshchaia teoriia sistem [The system approach and general systems theory]. Mysl.

12. Chervanov, D. M., Neikova, L. I. (1999). Menedzhment innovatsiino-investytsiinoho rozvytku pidpryiemstv Ukrainy [Management of the innovation and investment development of Ukrainian enterprises]. Znannia, KOO.

Ільчук Валерій Петрович - професор кафедри фінансів, банківської справи та страхування, Національний університет «Чернігівська політехніка» (вул. Шевченка, 95, м. Чернігів, 14035, Україна).

Ильчук Валерий Петрович - профессор кафедры финансов, банковского дела и страхования, Национальный университет «Черниговская политехника» (ул. Шевченко, 95, г. Чернигов, 14035, Украина).

Ilchuk Valerii - Professor Department of Finance, Banking and Insurance, Chernihiv Polytechnic National University (95 Shevchenka Str., 14035 Chernihiv, Ukraine)

E-mail: ivp5@ukr.net

Шпомер Тетяна Олександрівна - асистент кафедри фінансів, банківської справи та страхування, Національний університет «Чернигівська політехніка» (вул. Шевченка, 95, м. Чернігів, 14035, Україна).

Шпомер Татьяна Александровна - ассистент кафедры финансов, банковского дела и страхования, Национальный университет «Черниговская политехника» (ул. Шевченко, 95, г. Чернигов, 14035, Украина).

Shpomer Tetiana - Assistant Department of Finance, Banking and Insurance, Chernihiv Polytechnic National University (95 Shevchenka Str., 14035 Chernihiv, Ukraine).

E-mail: tanya_shpomer@ukr.net 